RESEARCH ARTICLE

\title{
Bioregulators Induced Modulation of Leaf Physiological Attributes and Severity of Papaya Ring Spot Viral Disease Symptom expression in Papaya
}

\author{
Akino $A^{1}$., K. Soorianathasundaram ${ }^{2 *}$, P. Paramaguru ${ }^{3}$, P. Jeyakumar ${ }^{4}$ and P. Muthulakshmi ${ }^{5}$ \\ ${ }^{1}$ Department of Fruit Science, Tamil Nadu Agricultural University, Coimbatore-3 \\ ${ }^{2}$ Horticultural college and Research Institute, Tamil Nadu Agricultural University, Coimbatore-3 \\ ${ }^{3}$ Horticultural college and Research Institute for Women, Tamil Nadu Agricultural University, Thiruchirappalli. \\ ${ }^{4}$ Department of Crop physiolo gy, Tamil Nadu Agricultural University, Coimbatore-3 \\ ${ }^{5}$ Department of Medicinal and Aromatic Crops, Tamil Nadu Agricultural University, Coimbatore-3
}

\begin{abstract}
The present study aimed to evaluate the influence of bioregulators on physiological attributes and yield components of TNAU Papaya CO. 8 variety during 2017 - 2018. The study involved two factors viz., growth retardants as factor I and stress tolerance promoting bioregulators as factor II. The treatments involving growth retardants (Factor I) were water spray $\left(G_{1}\right)$ as control, $250 \mathrm{ppm}$ of pro hexadione calcium $\left(\mathrm{G}_{2}\right), 500 \mathrm{ppm}$ of mepiquat chloride $\left(G_{3}\right)$ and 500 ppm of chlormequat chloride $\left(G_{4}\right)$. Similarly, the stress tolerance promoting bioregulators (Factor II) comprised of water spray as control $\left(\mathrm{S}_{1}\right), 100 \mathrm{ppm}$ of methyl jasmonate $\left(\mathrm{S}_{2}\right), 100 \mathrm{ppm}$ of salicylic acid $\left(\mathrm{S}_{3}\right)$ and $0.6 \mathrm{~g} / \mathrm{L}$ of strobilurins $\left(\mathrm{S}_{4}\right)$. The bioregulators were applied as foliar spray at the fourth and eighth months after transplanting. Initially, growth retardants were sprayed and one week after that, the stress tolerance promoting bioregulators were sprayed. Observations were recorded on number of leaves, leaf area index, leaf gas exchange parameters, papaya ring spot virusdisease incidence and yield components. Among the treatments, higher number of leaves (52.03) were observed in the combination involving $250 \mathrm{ppm}$ of prohexadione calcium and $100 \mathrm{ppm}$ of salicylic acid $\left(\mathrm{G}_{2} \mathrm{~S}_{3}\right)$ and leaf area index (2.73) was highly influenced by $500 \mathrm{ppm}$ of chlormequat chloride and $100 \mathrm{ppm}$ of salicylic acid $\left(\mathrm{G}_{4} \mathrm{~S}_{3}\right)$. Leaf gas exchange parameters were found to be superior with $250 \mathrm{ppm}$ of prohexadione calcium and 100 ppm of salicylic acid treatment (net photosynthetic rate $-16.46 \mu \mathrm{mol} \mathrm{cm}^{-2} \mathrm{~s}^{-1}$, stomatal conductance $-0.51 \mathrm{~mol} \mathrm{~m}^{-2} \mathrm{~s}^{-1}$, transpiration rate $-7.58 \mathrm{mmol} \mathrm{m}^{-2} \mathrm{~s}^{-1}$ ) as compared to control. Significant differences were also observed among the treatments for yield and yield components. The fruit yield was significantly improved by the treatment involving $500 \mathrm{ppm}$ of mepiquat chloride and $100 \mathrm{ppm}$ of salicylic acid $\left(\mathrm{G}_{3} \mathrm{~S}_{3}-61.76 \mathrm{~kg}\right.$ plant $\left.{ }^{-1}\right)$, indicating the possibility for enhancing papaya yield under field conditions where PRSV is prevalent.
\end{abstract}

Keywords: papaya;bioregulators;LAl;leaf gas exchange;papaya ring spot virus;yield

\section{INTRODUCTION}

Globally, among the tropical fruits that contribute to economic growth, income, food security and nutrition in many developing countries, papaya occupies a key position. It is a rich source of calcium and an excellent source of vitamins $A, B_{1}$, $B_{2}$ and $C$ (Oliveira and Vitoria, 2011). Among various diseases that plague papaya, the papaya ring spot virus (PRSV) continues to be a predominant one responsible for severe yield reduction and huge economic loss to the growers. PRSV belongs to the potyviridae family and is transmitted by the number of aphid species in a non-persistent manner. If the transmission occurs before flowering, the flower production will be affected, which could cause severe yield loss up to $85-90 \%$ (Lokhande et al. 1992, Hussain and Varma, 1994).

In recent years, many bioregulators have been widely used for enhancing vegetative growth, flowering, crop productivity, harvest, quality and as plant defense inducers under a range of biotic and abiotic stresses. Especially some bioregulators 
like prohexadione calcium, chlormequat chloride and mepiquat chloride have been used in many horticultural crops viz., apple, mango, strawberry, bell pepper etc. (Amarante et al., 2020; Mouco et al., 2013; Reekie et al., 2005; Sridhar et al., 2009). Bioregulators like methyl jasmonate (MeJA) and salicylic acid (SA), are generally involved in altering various functions from morphological to molecular levels in fruits. Apart from other recognized bioregulators, strobilurinsare used globally to combat many diseases, but when formulated with triazoles, they are gaining so much attention. It wasreportedto cause long-term changes in plant growth and metabolism, leading to higher biomass and yield (Bartett et al., 2001; Jeyakumar et al., 2014).Bioregulators may influence and modulate the physiological functions impaired by any stress, including biological stress. The symptoms of PRSV correspond to the stresses occurring at tissue level that are similar to abiotic stresses and are often managed using bioregulators. Hence, in the present study, the effects of foliar application of growth retardants and growth regulators on leaf physiological traits, yield components and PRSV disease expression in papaya variety TNAU Papaya C0.8 have been investigated to understand the modulation of leaf physiological parameters and PRSV disease incidence.

\section{MATERIAL AND METHODS}

The trial was carried out at the university orchard, Horticultural College and Research Institute, Tamil Nadu Agricultural University, Coimbatore, Tamil Nadu, India, located at an altitude of $426.6 \mathrm{~m}$ above mean sea level with latitude of $11^{\circ} \mathrm{N}$ and longitude of $77^{\circ} \mathrm{E}$. The variety used for the study was TNAU Papaya CO. 8 , which is red pulped dioecious variety with high yield potential of $200-220 \mathrm{t} / \mathrm{ha}$.

\section{Treatment details}

The experiment was laid out in a Factorial Randomized Block Design (FRBD) with two factors comprising of growth retardants as Factor I and stress tolerance promoting bioregulators as Factor II. Each factor was with four sub treatments, including a control (water spray) and hence totalof sixteen combinations were imposed. The growth retardants viz., prohexadione calcium $\left(\mathrm{C}_{10} \mathrm{H}_{10} \mathrm{O}_{5} \mathrm{Ca}\right)$, mepiquat chloride $\left(\mathrm{C}_{7} \mathrm{H}_{16} \mathrm{Cl} \mathrm{N}\right)$ and chlormequat chloride $\left(\mathrm{C}_{5} \mathrm{H}_{13} \mathrm{Cl}_{2} \mathrm{~N}\right.$, ) and the stress tolerance promoting bioregulators viz., methyl jasmonate (C 13 $\mathrm{H} 2003$ ), salicylic acid $\left(\mathrm{C}_{7} \mathrm{H}_{6} \mathrm{O}_{3}\right)$ and strobilurins [Tebuconazole $\left(\mathrm{C}_{16} \mathrm{H}_{22} \mathrm{CIN}_{3} \mathrm{O}\right.$ ) and Trifloxystrobin (C $\left.{ }_{20} \mathrm{H}_{19} \mathrm{~F}_{3} \mathrm{~N}_{2} \mathrm{O}_{4}\right)$ ] were given as foliar spray as per the treatment details. The details of the treatment combinations used for the study are presented in table 1.

Table 1. Treatment details of the experiment

\begin{tabular}{ll}
\hline Factor I: Growth retardants & Factor II: Stress tolerance promoting bioregulators \\
\hline $\mathrm{G}_{1}$ - Control ( water spray) & $\mathrm{S}_{1}$ - Control (water spray) \\
$\mathrm{G}_{2}$ - Prohexadione calcium - $250 \mathrm{ppm}$ & $\mathrm{S}_{2}$ - Methyl jasmonate - $100 \mathrm{ppm}$ \\
$\mathrm{G}_{3}$ - Mepiquat chloride - $500 \mathrm{ppm}$ & $\mathrm{S}_{3}$ - Salicylic acid - $100 \mathrm{ppm}$ \\
$\mathrm{G}_{4}$ - Chlormequat chloride - $500 \mathrm{ppm}$ & $\mathrm{S}_{4}$ - Strobilurins - $0.6 \mathrm{~g} / \mathrm{L}$ \\
\hline
\end{tabular}

\section{Stage of application}

Since phloem flow is restricted due to PRSV, foliar sprays were resorted as practical approach to overcome the biological stress. The incidences of PRSV normally hamper the flowering, fruit set and fruit developmental phases and in order to overcome the stress, the bioregulator treatments were applied as foliar sprays at two phases i.e., fourth (a month just prior to flowering) and eighth month (a month prior to maturity and harvest) after transplanting (MAT) as per the treatment details. Initially, growth retardants were sprayed as per the treatment details and one week after the application of growth retardants, stress tolerance promoting bioregulators were sprayed.

\section{Observations recorded}

Observations on the following leaf parameters and PRSV disease expression were recorded at the time of fruiting

\section{Number of leaves}

Total number of functional leaves present on the plant was counted at the time of fruiting and expressed in numbers

\section{Leaf area index}

The leaf area index was calculated using the formula given by Watson (1952).

Leaf area index = Leaf area per plant/ Area occupied by the plant

\section{Chlorophyll index}

Chlorophyll index value was recorded by using the portable chlorophyll meter/ SPAD (Soil and Plant Analytical Division) meter [MINOLTA, SPAD 502 plus, Japan]. It is a hand-held device based on 
two light-emitting diodes and a silicon photodiode receptor that measures leaf transmittance in the red (measuring wavelength - $650 \mathrm{~nm}$ ) and infrared (940 $\mathrm{nm}$; a reference wavelength used to adjust for nonspecific differences between samples) regions of the electromagnetic spectrum. These transmittance values are used by the device to derive a relative SPAD meter value (upto 50) proportional to the amount of chlorophyll in the leaves (Uddling et al., 2007). In the present study, the chlorophyll indices were recorded at sixth leaf from the top of the plant.

\section{Leaf gas exchange parameters}

Leaf gas exchange measurements were recorded by using Portable Photosynthesis System (PPS) (Model LI-6400 of LICOR inc., Lincoln, Nebraska, USA) equipped with a halogen lamp (6400-02B LED) positioned on the cuvette. With PPFD at $1200 \mu \mathrm{mol}$ photons $\mathrm{m}^{-2} \mathrm{~s}^{-1}$ and $55-60 \%$ of relative humidity, the readings were taken between $1100 \mathrm{~h}$ to 1230 $\mathrm{h}$ when the sky is clear. Using PPS system, the gas exchange parameters viz., net photosynthetic rate $(\mathrm{Pn})$, stomatal conductance (gs) and transpiration rate $(E)$ were recorded at sixth leaf from the top of the plant.

\section{PRSV scoring and disease severity}

Papaya Ring Spot Virus (PRSV) disease incidence was recorded using the following score chart (Table 2), having six delineating scores (Dhanam, 2006). Since foliar sprays were given to prevent any data overlap from the peripheral rows, that may receive the drift effect of spray treatments from a neighbouring plot, observations were taken from three bearing plants in the middle of each treatment plot for scoring.

\section{PRSV score chart}

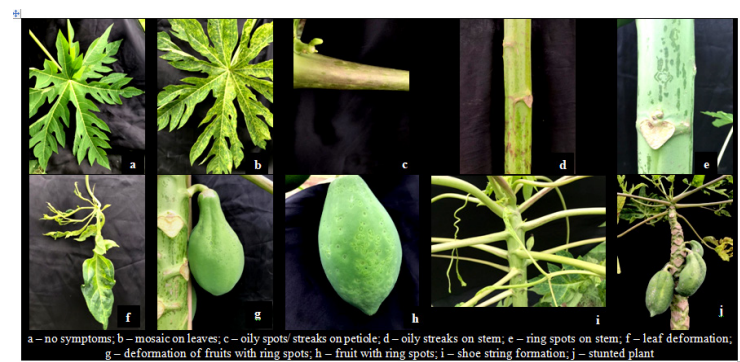

Table 2. Symptoms and score chart of PRSV

\begin{tabular}{clc}
\hline S. No & \multicolumn{1}{c}{ Description of the symptoms } & Score \\
\hline 1. & No symptoms & 0 \\
2. & Mild mosaic (or) oily spots, streaks on petiole (or) stem, oily spots on fruits & 1 \\
3. & Mild mosaic and oily streaks/ spots on petiole/ stem and ring spots on fruits & 3 \\
4. & Oily spots/ streaks on petiole (or) stem (or) ring spots on fruits & 5 \\
5. & Oily spots/streaks on petioles, stem or on fruits (ring spots), severe mosaic or blistening on & 7 \\
& leaves and leaf deformation + severe leaf reduction / mild fruit deformation with ring spots & 9 \\
6. $\quad$ Oily spots/ streaks on petiole or stem and shoe string formation or severe fruit development & with ring spots and stunted plants
\end{tabular}

The disease severity was calculated by using the following formula:

PRSV $($ per cent $)=($ Total score of all plants / Total number of plants $) \times(100 /$ max score $)$

\section{Number of fruits}

Total number of fruits set on the plant was counted when first harvest commenced and expressed in numbers

\section{Yield (kg plant $\left.{ }^{-1}\right)$}

The mean yield was estimated by the product of average number of fruits per plant counted till tenth month after planting with mean fruit weight of the first five harvested fruits and expressed in kilogram per plant.

\section{Statistical analysis}

The experiment was laid out in Factorial Randomized Block Design (FRBD) with four treatments in each of the two factors (16 treatment combinations) and replicated thrice. The mean effects were compared after subjecting the data collected by Factorial ANOVA test with SPSS 16.0 software and critical differences were worked out at five percent probability level.

\section{RESULTS AND DISCUSSION}

\section{Influence of bioregulators on number of leaves of TNAU Papaya CO.8}

Among the plants which received the treatments, the average number of leaves ranged from 27.01 to 52.03 (Table 3). A general reduction in leaf number was recorded due to growth retardants. The reduction was significant at $500 \mathrm{ppm}$ of mepiquat chloride $\left(G_{3}\right)(34.79)$ as compared to control $\left(G_{1} S_{1}\right)$ (38.00). Growth retardants in combination with stress tolerance promoting bioregulators, however, resulted in higher leaf production, especially in the combination of $250 \mathrm{ppm}$ of prohexadione calcium along with $100 \mathrm{ppm}$ of methyl jasmonate $\left(\mathrm{G}_{2} \mathrm{~S}_{2}\right.$ 52.03) and $100 \mathrm{ppm}$ of salicylic acid $\left(\mathrm{G}_{2} \mathrm{~S}_{3}-47.76\right)$. 
When the main effects of stress tolerance promoting bioregulatorsare considered over the impact of growth retardants, 100 ppm of salicylic acid $\left(S_{3}\right)$ recorded higher mean leaf number (43.59).

This demonstrates the positive and significant impact of salicylic acid despite prior treatment with growth retardants on leaf production. This probably could have been due to increased chlorophyll and carotene contents promoted by salicylic acid in leaves and reduction in the biosynthesis of endogenous ethylene, leading to lower senescence rates, as reported earlier by Hassoon and Abduljabbar (2020). An increase in leaf numbers with the salicylic acid application was similarly evident in cucumber (Abbasi et al., 2020)

Table 3. Influence of bioregulators on number of leaves and leaf area index at fruiting stage

\begin{tabular}{|c|c|c|c|c|c|c|c|c|c|c|}
\hline \multirow[b]{2}{*}{ Treatment } & \multicolumn{5}{|c|}{ Number of leaves } & \multicolumn{5}{|c|}{ Leaf area index } \\
\hline & $s_{1}$ & $\mathbf{S}_{2}$ & $\mathbf{S}_{3}$ & $\mathbf{S}_{4}$ & Mean & $\mathrm{s}_{1}$ & $\mathbf{S}_{2}$ & $\mathbf{S}_{3}$ & $\mathbf{S}_{4}$ & Mean \\
\hline $\mathrm{G}_{1}$ & 38.00 & 27.01 & 42.15 & 36.33 & 35.87 & 1.86 & 0.84 & 2.07 & 1.77 & 1.64 \\
\hline $\mathrm{G}_{2}$ & 32.01 & 52.03 & 47.76 & 38.09 & 42.47 & 1.26 & 1.73 & 2.20 & 1.33 & 1.63 \\
\hline $\mathrm{G}_{3}$ & 36.37 & 27.07 & 37.07 & 38.67 & 34.79 & 2.03 & 1.30 & 2.13 & 1.42 & 1.72 \\
\hline $\mathrm{G}_{4}$ & 25.34 & 29.17 & 47.37 & 40.11 & 35.50 & 1.45 & 1.68 & 2.73 & 2.24 & 2.02 \\
\hline \multirow[t]{2}{*}{ Mean } & 32.93 & 33.82 & 43.59 & 38.30 & & 1.65 & 1.39 & 2.28 & 1.69 & \\
\hline & G & S & $G S$ & & & G & S & $G S$ & & \\
\hline SEd & 0.27 & 0.27 & 0.54 & & & 0.02 & 0.02 & 0.04 & & \\
\hline CD (0.05) & 0.56 & 0.56 & 1.12 & & & 0.04 & 0.04 & 0.98 & & \\
\hline
\end{tabular}

\section{Influence of bioregulators on leaf area index of TNAU Papaya C0.8}

The leaf area indices were influenced significantly by the application of growth retardants and stress tolerance promoting bioregulators. The leaf area indices ranged from 0.84 to 2.73 in the present study (Table 3 ). Among the growth retardants, while the indices were reduced by application of 250 ppm of prohexadione calcium (1.63) and 500 ppm of chlormequat chloride (1.72) as compared to control (1.86), mepiquat chloride at $500 \mathrm{ppm}$ improved the leaf area index when combined with water spray (2.03).

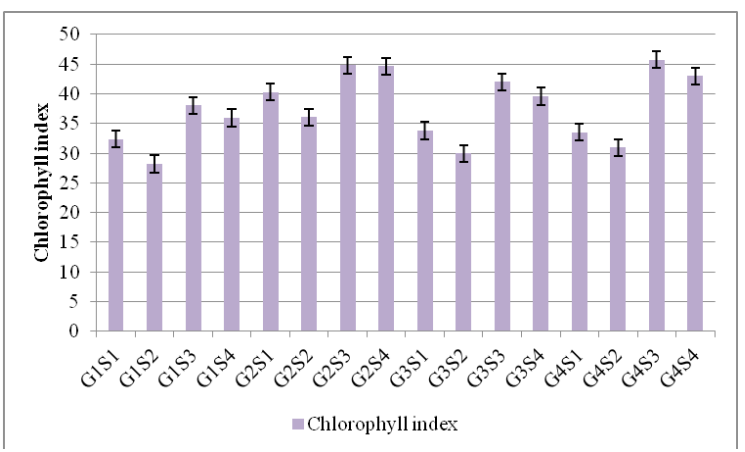

Fig. 1 Influence of bioregulators combinations on Chlorophyll index of papaya

Among the stress tolerance promoting bioregulators, $100 \mathrm{ppm}$ of salicylic acid $\left(\mathrm{S}_{3}\right)$ registered the highest mean leaf area index over the effects of growth retardant treatments or water spray (2.28)

$107|10-12| 4$
When both the factors are combined, $G_{4} S_{3}$, $\mathrm{G}_{4} \mathrm{~S}_{4}$ and $\mathrm{G}_{2} \mathrm{~S}_{3}$ recorded higher leaf area indices (2.73, 2.24 and 2.20). Application of 500 ppm of chlormequat chloride though generally has resulted in the lower number of leaves, when subsequently followed up with 100 ppm of salicylic acid $\left(G_{4} S_{3}\right)$, it resulted in higher leaf area index. Similar response was also observed with 250 ppm of prohexadione calcium in combination with 100 ppm of salicylic acid $\left(\mathrm{G}_{2} \mathrm{~S}_{3}\right)$ and also with $500 \mathrm{ppm}$ of chlormequat chloride in combination with $0.6 \mathrm{~g} / \mathrm{L}$ of strobilurins $\left(\mathrm{G}_{4} \mathrm{~S}_{4}\right)$ with the indices of 2.20 and 2.24 respectively.

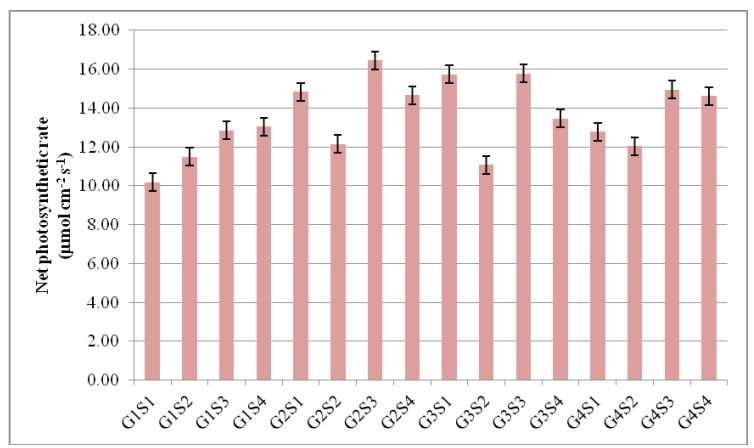

Fig. 2. Influence of bioregulators on net photosynthetic rate in TNAU Papaya C0.8

Higher leaf area indices relate to higher photosynthetic surface for harnassing photosynthetically active radiation (PAR) and encourage the biomass which can lead to higher yield. Both $500 \mathrm{ppm}$ of mepiquat chloride and chlormequat chloride registered higher leaf area 
indices as compared to prohexadione calcium when their main effects were compared over the influence of growth retardants.

The combination of $\mathrm{G}_{4} \mathrm{~S}_{3}(500$ ppm of chlormequat chloride with $100 \mathrm{ppm}$ of methyl jasmonate) or $\mathrm{G}_{2} \mathrm{~S}_{3}$ (250 ppm of prohexadione calcium with 100 ppm of salicylic acid) recorded better leaf area index as compared to $G_{1} S_{1}$ or the combination of $\mathrm{G}_{2} \mathrm{~S}_{2}$. This data again clearly demonstrates that favorable influence of salicylic acid or strobilurins in moderating the physiological stress the crop may experience in the field either due to abiotic factors or due to PRSV incidence. Both salicylic acid and strobilurins are known to affect leaf area indices in many crops like common bean, tomato and groundnut (Sadeghipour and Aghaei, 2012; Sivakumar and Srividhya, 2018; Sowmyapriyaet al., 2015).

Table 5. Main effects of stress tolerance promoting bioregulators on chlorophyll index and leaf gas exchange parameters

\begin{tabular}{|c|c|c|c|c|}
\hline Treatments & Chlorophyll index & $\begin{array}{l}\text { Net photosynthetic rate } \\
\left.(\mu \mathrm{mol} \mathrm{cm})^{-2} \mathrm{~s}^{-1}\right)\end{array}$ & $\begin{array}{l}\text { Stomatal conductance } \\
\qquad\left(\mathrm{mol} \mathrm{m}^{-2} \mathrm{~s}^{-1}\right)\end{array}$ & $\begin{array}{c}\text { Transpiration rate } \\
\left(\mathrm{mol} \mathrm{m}^{-2} \mathrm{~s}^{-1}\right)\end{array}$ \\
\hline $\mathrm{S}_{1}$ & 34.99 & 13.39 & 0.35 & 6.24 \\
\hline $\mathrm{S}_{2}$ & 31.28 & 11.69 & 0.29 & 4.88 \\
\hline $\mathrm{S}_{3}$ & 42.64 & 15.00 & 0.41 & 6.95 \\
\hline $\mathrm{S}_{4}$ & 40.80 & 13.95 & 0.36 & 6.68 \\
\hline SE & 0.44 & 0.11 & 0.003 & 0.05 \\
\hline CD (0.05) & 0.90 & 0.23 & 0.006 & 0.11 \\
\hline
\end{tabular}

\section{Influence of bioregulators on chlorophyll content of TNAU Papaya CO.8}

Although the number of leaves and leaf area index are important parameters in determining the photosynthetic capacity, the chlorophyll content is directly related to the photosynthetic efficiency of the crop under the incidence of PRSV or with any other biotic or abiotic stresses.

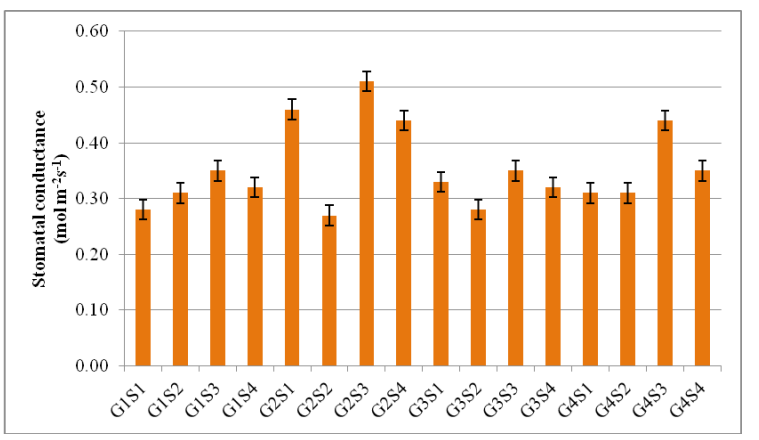

Fig. 3. Influence of bioregulators on stomatal conductance in TNAU Papaya C0.8

The chlorophyll indices ranged from 28.20 to 45.71 among the different treatments, while in control, it was 32.37. Lower chlorophyll indices were registered in the combinations $G_{1} S_{2}$ (28.20), $G_{3} S_{2}$ (29.93) and $\mathrm{G}_{4} \mathrm{~S}_{2}$ (30.92) than the control (Fig. 1). In the other treatments or treatment combinations, the chlorophyll indices were generally higher than the control. Althoughchlormequat chloride is a growth retardant, it may influence the chlorophyll indices by stimulating chlorophyll bio-synthesis, chloroplast differentiation and photosynthetic enzymes (Grewal et al., 1993; Appleby et al., 1966). The reason for the reduction in chlorophyll index in methyl jasmonate treated plants in general or in combination with either mepiquat chloride or chlormequat chloride can be attributed to possible down-regulation of $\mathrm{NO}^{3-}$ ions and influence on ethylene biosynthesis as reported with exogenous application of methyl jasmonate (Rossato et al., 2002).

In the treatment with salicylic acid alone or its combinations with growth retardants, generally higher chlorophyll indices were registered by the plants in the present study. The chlorophyll index as determined by SPAD recordings was 42.64 with $100 \mathrm{ppm}$ of salicylic acid when the overall effect was considered (Table 5). Strobilurins $(0.6 \mathrm{~g} / \mathrm{L})$ also registered higher chlorophyll indices either alone (40.80) or in combination with growth retardants. These results indicate that both strobilurins and salicylic acid could be advantageously employed to maintain the photosynthetic efficiency of the crop under stress. Salicylic acid seems to be more favorable than strobilurins for increasing leaf area indices and improving chlorophyllindices.

\section{Influence of bioregulators on leaf gas exchange parameters of TNAU Papaya C 0.8}

The parameters viz., net photosynthetic rate, stomatal conductance and transpiration rate should be optimally regulated for better assimilation of photosynthetic resources. The influence of treatment combinations on net photosynthetic rate is depicted in Fig. 2.

Among the treatments, the net photosynthetic rate ranged from $10.18 \mu \mathrm{mol} \mathrm{cm}^{-2} \mathrm{~s}^{-1}\left(\mathrm{G}_{1} \mathrm{~S}_{1}\right)$ to 16.46 $\mu \mathrm{mol} \mathrm{cm}^{-2} \mathrm{~s}^{-1}\left(G_{2} S_{3}\right)$. When the main effects were 
considered, higher net photosynthetic rates were registered by $250 \mathrm{ppm}$ of prohexadione calcium $\left(14.53 \mu \mathrm{mol} \mathrm{cm} \mathrm{cm}^{-2} \mathrm{~s}^{-1}\right)$ and $500 \mathrm{ppm}$ of mepiquat chloride (14.01 $\mu \mathrm{mol} \mathrm{cm}^{-2} \mathrm{~s}^{-1}$ ) among the growth retardants (Table 4). The observed increases in stomatal conductance and transpiration rate with prohexadione calcium applied plants could be due to increases in the level of endogenous cytokinin as reported in Viciafaba and apricot (Bekheta et al., 2009; Thakur et al., 2019).

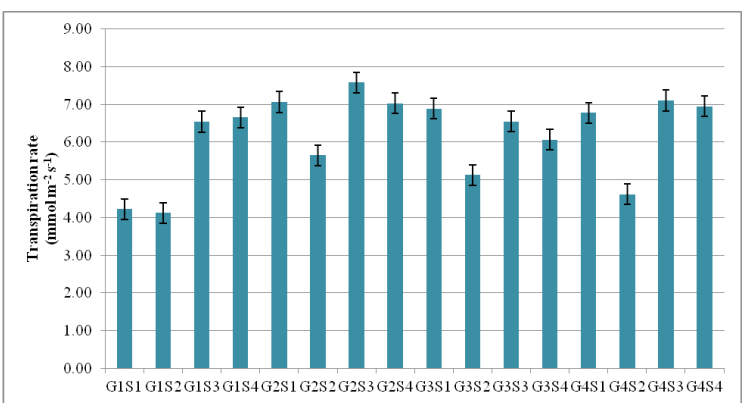

Fig. 4. Influence of bioregulators on transpiration rate in TNAU Papaya C0.8

Among the stress tolerance promoting bioregulators, salicylic acid resulted in higher main effect in net photosynthetic effect $\left(15.00 \mu \mathrm{mol} \mathrm{cm}{ }^{-2}\right.$ $\left.\mathrm{s}^{-1}\right)$. Whenever salicylic acid was involved, high net photosynthetic rate was positively influenced as compared to control or as compared to corresponding growth retarding treatments involved in combination with salicylic acid. (Table 5)

Although with 100 ppm of methyl jasmonate, net photosynthetic rate was marginally higher as against control or in combination with growth retardants, the beneficial effect was lesser than that of salicylic acid or strobilurin combinations with growth retardants. Among different bioregulators, plants treated with methyl jasmonate recorded lower stomatal conductance. It is known that plants exposed to methyl jasmonate resulted in stomatal closure and reduced stomatal conductance, leading to reduced leaf photosynthesis due to limited $\mathrm{CO}_{2}$ availability (Jiang et al., 2020; Jung, 2004 and Attaran et al., 2014).

While stomatal conductance in control $\left(\mathrm{G}_{1} \mathrm{~S}_{1}\right)$ was $0.28 \mathrm{~mol} \mathrm{~m}^{-2} \mathrm{~s}^{-1}$, it ranged from 0.27 to $0.31 \mathrm{~mol}$ $\mathrm{m}^{-2} \mathrm{~s}^{-1}$ in methyl jasmonate and growth retardants combinations (Fig. 3). Salicylic acid treatments could influence higher net photosynthetic rate by higher stomatal conductance as revealed in the present study. In the combinations of growth retardants with salicylic acid, the stomatal conductance ranged from $0.35\left(\mathrm{G}_{3} \mathrm{~S}_{3}\right)$ to $0.52 \mathrm{~mol} \mathrm{~m}^{-2} \mathrm{~s}^{-1}\left(\mathrm{G}_{2} \mathrm{~S}_{3}\right)$. Strobilurins also recorded marginally higher stomatal conductance as well as net photosynthetic rate as compared to methyl jasmonate but not as effective as salicylic acid.
The favourable influence of salicylic acid on net photosynthetic rate was attributed to positive influence on chlorophyll and carotenoid contents and the activity of enzymes such as RuBisCO (ribulose-1, 5- bisphosphate carboxylase/oxygenase) and carbonic anhydrase (Mateo et al., 2004; Melotto et al., 2006; Fariduddin et al., 2003; Slaymaker et al., 2002). Further, salicylic acid was reported to prevent auxin oxidation and keeping the auxin level elevated, which in turn increases the net photosynthetic rate and nitrate reductase activity (Ahmad et al., 2001).

In the growth retardant treatment alone or in combination with prohexadione calcium, there was generally a lower transpiration rate (Table 4 \& Fig 4). In the control $\left(\mathrm{G}_{1} \mathrm{~S}_{1}\right)$ and $100 \mathrm{ppm}$ of methyljasmonate alone was employed, the transpiration rate was very low. Similarly, in all the combinations involving methyl jasmonate, the transpiration rate was lower. This may be due to high viral accumulation and no positive influence of methyl jasmonate in modulating PRSV incidence. Synkovaet al. (2006) related the reduced stomatal conductance and transpiration rate to a high accumulation of viral aggregates inside the guard cells in Nicotiana tabacum L. In a crop like papaya, which is affected by PRSV rapidly, such viral accumulation may lead to lower transpiration rate, stomatal conductance and reduced net photosynthetic rate.

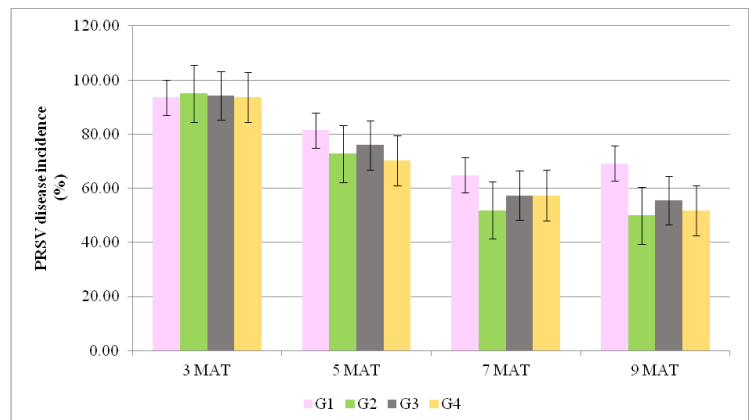

Fig. 5. Main effects of growth retardants on PRSV incidences at third, fifth, seventh and ninth month after transplanting

Influence of bioregulators on Papaya Ringspot Virus Disease incidence and its severity in TNAU Papaya $\mathbf{C} 0.8$

The disease symptoms appeared in all the plants and no significant differences were observedinthe third month after transplanting. The disease severity ranged from 62.95 per cent to 92.58 per cent in the fifth month after transplanting (Fig. 7).

Significant reduction in PRSV incidence was observed in all the treatments involving growth retardants and stress tolerance promoting bioregulators at $5^{\text {th }}, 7^{\text {th }}$ and $9^{\text {th }}$ months after transplanting. 
At $7^{\text {th }}$ and $9^{\text {th }}$ months after transplanting, a similar trend was observed among the treatments studied. Although the highest reduction in PRSV was observed with $\mathrm{G}_{2}$ during the $5^{\text {th }}$ month, subsequently, the plants treated with salicylic acid $\left(\mathrm{G}_{2} \mathrm{~S}_{3}\right)$ in general registered significantly the lowest incidence. The PRSV incidence at $7^{\text {th }}$ month with the estimated main effect of stress tolerance promoting bioregulators was 44.44 per cent in the treatment 100 ppm of salicylic acid $\left(\mathrm{S}_{3}\right)$.

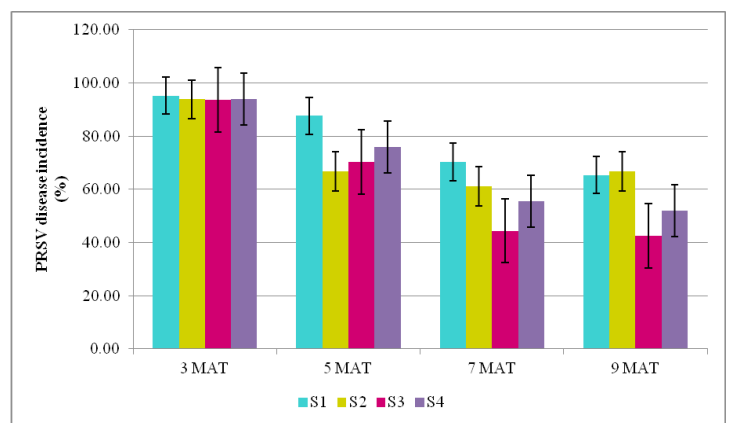

Fig. 6. Main effects of stress tolerance bioregulators on PRSV incidences at third, fifth, seventh and ninth month after transplanting

The main effects of other stress tolerance promoting bioregulators were 61.10 per cent with $100 \mathrm{ppm}$ of methyl jasmonate $\left(\mathrm{S}_{2}\right)$ and $55.55 \mathrm{per}$ cent with $0.6 \mathrm{~g} / \mathrm{L}$ of strobilurins $\left(\mathrm{S}_{4}\right)$. Even at $9^{\text {th }}$ month after transplanting, salicylic acid continued to result in the lowest PRSV incidence of 42.59 per cent as main effect across the growth retardants (Fig. 5 \& 6).

The reduction in the observed PRSV incidences from 92.58 per cent at $5^{\text {th }}$ month after transplanting to 77.77 percent at $7^{\text {th }}$ month after transplanting in $\mathrm{G}_{1} \mathrm{~S}_{1}$ can be attributed to the factor of leaf production over the time and symptom expression in the young leaf produced (Fig. 8). This could be also due to earlier senescence of affected leaves in the PRSV affected plants. Since, the observations are based on relative scores on the foliage of the plant as described in the methodology.

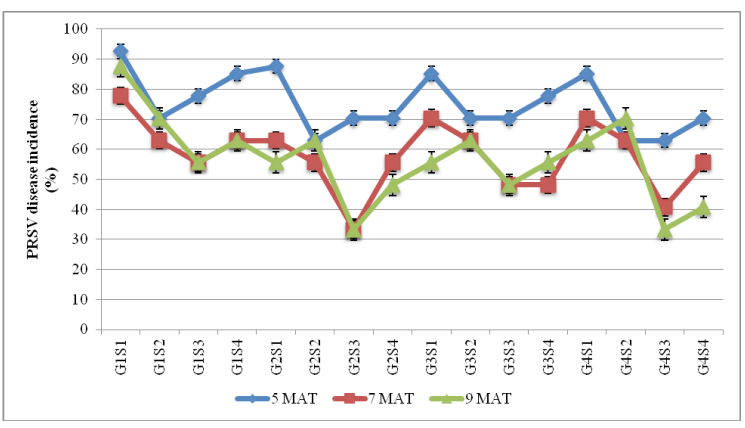

Fig. 7 Incidence of PRSV at fifth, seventh and ninth month after transplanting

The combination of $250 \mathrm{ppm}$ of prohexadione calcium with 100 ppm of salicylic acid, in general, resulted in lower PRSV incidences upto $9^{\text {th }}$ month after transplanting. The PRSV incidence was only 33.33 per cent in the combination of $\mathrm{G}_{2} \mathrm{~S}_{3}$ or $\mathrm{G}_{4} \mathrm{~S}_{3}$ at $9^{\text {th }}$ month after transplanting as compared to 87.64 per cent in control $\left(G_{1} S_{1}\right)$. Possible mechanism for PRSV tolerance by Prohexadione calcium can be modulated by anatomical changes in plant tissue associated with reduced growth. It was reported that, young, expanding shoot tissue is characterized by the formation of protoxylem; and conversion of protoxylem to lignified metaxylem elements with thickened cell walls which provide structural resistance to insect vectors (McGrath et al., 2009).

The significant reduction in PRSV incidence as determined by the lowest score values in $100 \mathrm{ppm}$ of salicylic acid treated plants, especially with 500 ppm of mepiquat chloride and 250 ppm of prohexadione calcium reveals immense possibilities for managing this viral disease and for sustainable crop growth in the field conditions. Exogenous application of salicylic acid is reported to induce some degree of resistance to viruses even in plants that do not possess a corresponding resistance gene and that would, in normal circumstances, be completely susceptible. It was reported that SA can inhibit the development of virus disease in plants in two ways: either by inhibiting replication of the virus at the initial point of infection or by delaying the movement of the virus out of the inoculated tissue. Salicylic acid may also interfere with long-distance virus movement in an indirect manner by changing the pattern of photosynthate translocation by inducing changes in respiration by induction of alternative oxidase (AOX) gene expression and activity (Naylor et al., 1998).

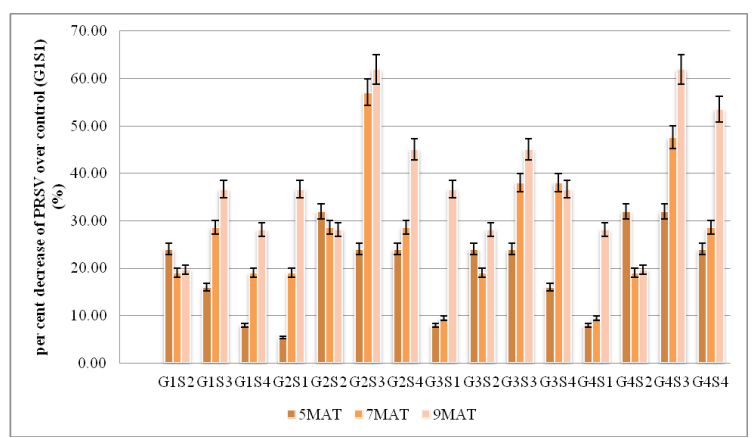

Fig. 8 Per cent decrease of PRSV over control $\left(G_{1} S_{1}\right)$ at fifth, seventh and ninth month after transplanting

Impact of bioregulators on number of fruits and yield (kg plant ${ }^{-1}$ ) of TNAU Papaya C0.8

Among the treatment combinations significantly higher number of fruits were registered byprohexadione calcium with methyl jasmonate (42.17), prohexadione calcium with salicylic acid (41.13) and mepiquatchloride with salicylic acid (42.01). The increase in number of fruits was to an 
extent of 68.40 per cent in $\mathrm{G}_{2} \mathrm{~S}_{2}, 67.78$ per cent in $\mathrm{G}_{3} \mathrm{~S}_{3}$ and 64.27 per cent in $\mathrm{G}_{2} \mathrm{~S}_{3}$ as compared to control $\left(G_{1} S_{1}-28.44\right)$.

When the main effects are considered, among the growth retardants, spray of $500 \mathrm{ppm}$ of mepiquat chloride and 250 ppm of prohexadione calcium resulted in comparatively higher fruit yield in terms of fruit weight. Similarly, 100 ppm of salicylic acid and $0.6 \mathrm{~g} / \mathrm{L}$ of strobilurins registered higher yield among the stress tolerance promoting bioregulators. Among the combinations, the highest yield was recorded in 500 ppm of mepiquat chloride in combination with $100 \mathrm{ppm}$ of salicylic acid $\left(\mathrm{G}_{3} \mathrm{~S}_{3}-61.76 \mathrm{~kg}\right.$ plant $\left.{ }^{-1}\right)$ followed by 500 ppm of chlormequat chloride with $0.6 \mathrm{~g} / \mathrm{L}$ of strobilurins $\left(\mathrm{G}_{4} \mathrm{~S}_{4}-58.78\right.$ kgplant $\left.^{-1}\right)$ as compared to $31.01 \mathrm{~kg}$ plant ${ }^{-1}$ in control $\left(\mathrm{G}_{1} \mathrm{~S}_{1}\right)$ (Fig. 9).

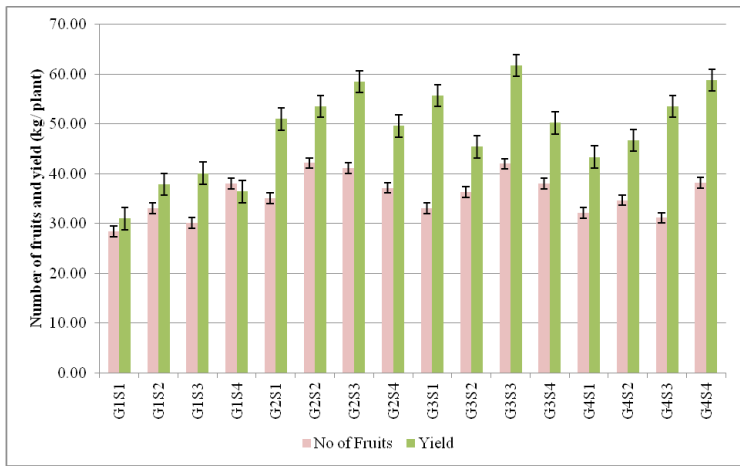

Fig. 9 Influence of bioregulators on number of fruits and yield (kg/ plant) in papaya var. TNAU Papaya CO. 8

The yield increase in plants treated with salicylic acid could be attributed to improved leaf production, enhanced leaf area, higher chlorophyll index, improved photosynthetic efficiency and reduction in PRSV development during plant growth, as discussed earlier. Next to salicylic acid, it is observed that, strobilurins in combination with mepiquat chloride could be advantageous in modulating the physiology of the crop for better yield and reducing the impact of PRSV on the crop performance.

\section{CONCLUSION}

Application of 500 ppm of mepiquat chloride at fourth and eighth month after transplanting followed by a spray of either 100 ppm of salicylic acid or $0.6 \mathrm{~g} / \mathrm{L}$ of strobilurins could help to achieve economically higher yields by reducing PRSV symptom development or expressions and influencing the leaf physiological processes such as chlorophyll index, net photosynthetic rate, stomatal conductance and transpiration rate positively.

\section{REFERENCES}

Abbasi, F., A. Khaleghi and A. Khadivi.2020. The Effect of Salicylic Acid on Physiological and Morphological
Traits of Cucumber (Cucumissativus L. cv. Dream). GesundePflanzen 72, 155-162. https:// doi.org/10.1007/s10343-019-00496-0

Ahmad A, S. Hayat, Q. Fariduddin and I. Ahmad. 2001. Photosynthetic efficiency of plants of Brassica juncea treated with chloro substituted auxins. Photosynthetica 39, 565-568.

Amarante, C. V. T., J. P. G. Silveira, C. A. Steffens, S. T.de Freitas,E. J. Mitcham and A. Miqueloto. 2020. Post-bloom and preharvest treatment of 'Braeburn' apple trees with prohexadionecalcium and $\mathrm{GA}_{4+7}$ affects vegetative growth and postharvest incidence of calcium-related physiological disorders and decay in the fruit. ScientiaHortic., 261, 108919. https://doi. org/10.1016/j.scienta.2019.108919.

Appleby, A. P., W. E. Kronstadt and C. R. Rhode. 1966. Influence of (2-chloroethyl) trimethylammonium chloride (CCC) on wheat when applied as seed treatment. Agron. J., 58:435-437. http://dx.doi. org/10.2134/agronj1966.000219620058000 40022x.

Attaran, E., I. Major, J. Cruz, B. Rosa, A. Koo, J. Chen, D. Kramer, S.Y. He and G. Howe.2014. Temporal dynamics of growth and photosynthesis suppression in response to jasmonate signaling. PI. Physiol., 165, 1302-1314.

Bartett, D. W., Clough, J. M., Godfrey, C. R. A., Godwin, J. R., Hall, A. A., Heaney, S. P. 2001. Understanding the strobilurin fungicides.Pestic.Outlook.12, 143-148. doi: 10.1039/b106300f

Bekheta MA, Abdelhamid MT, El-Morsi AA.2009. Physiological response of Viciafaba to prohexadionecalcium under saline conditions. PlantaDaninha; 27(4):767-779

Dhanam, S. 2006. Studies on papaya ring spot disease. M.Sc. thesis submitted to Tamil Nadu Agric. Univ.

Fariduddin Q, Hayat S, Ahmad A. 2003. Salicylic acid influences net photosynthetic rate, carboxylation efficiency, nitrate reductase activity, and seed yield in Brassica juncea. Photosynthetica 41, 281-284.

Grewal, H.S., Kolar, J.S., Cheema, S.S. \& Sing, G. 1993. Studies on the use of growth regulators in relation to nitrogen for enhancing sink capacity and yield of gobhisarson (Brassica napus). Ind. J. Plant Physiology, 36:1-4.

Hassoon, A. S. and Abduljabbar, I. A. 2020. Review on the role of salicylic acid in plants. Book chapter In: Sustainable crop production.Pp 1 - 7. DOI: 10.5772/intechopen.83521.

Hussain S and Varma A A. 1994.Occurrence of papaya ringspot virus from Amritsar (Punjab).Indian J.Phytopathol. Res. 7: 77-8.

Jeyakumar, P., R. Nagajothi and C. N, Chandrasekhar. 2014. Trifloxystrobin induced changes in the postharvest behaviour of Tomato fruits. Agrotechnol., 2:4. $2^{\text {nd }}$ International Conference on Agricultural \& Horticultural Sciences

Jiang, Y., J. Ye, B. Rasulov and U. Niinemets. 2020. Role of Stomatal Conductance in Modifying the Dose Response of Stress-Volatile Emissions in 
Methyl Jasmonate Treated Leaves of Cucumber (Cucumissativus). Intl J. Mol. Sci. 21(3):1018. DOI: $10.3390 / \mathrm{ijms} 21031018$

Jung, S. 2004. Effect of chlorophyll reduction in Arabidopsis thaliana by methyl jasmonate or norflurazon on antioxidant systems. J. Plant Physiol. Biochem., 42, 231-255.

Lokhande N M, Moghe P G, Matteand A D and Hiware B J. 1992.Occurrence of papaya ringspot virus in Vidharbha regions of Maharastra. J. Soils and Crops 2: 36-9

Mateo A, Muhlenbock P, Rusterucci C, Chang CC, Miszalski Z, Karpinska B, Parker JE, Mullineaux PM, Karpisnki S. 2004. LESION SIMULATING DISEASE1 is required for acclimation to conditions that promote excess excitation energy. PI. Physiol. 136, 2818-2830.

McGrath, M. J., J. M. Koczan, M. M. Kennelly and G. W. Sundin. 2009. Evidence that ProhexadioneCalcium Induces Structural Resistance to Fire Blight Infection. doi:10.1094/ PHYTO-99-5-0591

Melotto M, Underwood W, Koczan J, Nomura K, He SY. 2006. Plant stomata function in innate immunity against bacterial invasion. Cell 126, 969-980.

Mouco, M. A. C., E.O. Ono, J. D. Rodrigues and G. J. N. Silva.2013. Plant Regulators on Vegetative Growth of 'Tommy Atkins' Mangoes.Proc.IX th Intl. Mango Symposium, Ed.: Ping Lu Acta Hort. 992, ISHS.

Naylor, M., A. M. Murphy, J. O. Berry and J. P. Carr. 1998. Salicylic Acid Can Induce Resistance to Plant Virus Movement. Molecular Plant-Microbe Interactions.11 (9): 860-868

Oliveira,J. G. and A. P. Vitoria. 2011. Papaya: Nutritional and pharmacological characterization, and quality loss due to physiological disorders. An overview. Food Res. Intl. 44 (5) pp: 1306-1313

Reekie, J. Y., Hicklenton, P. R. and Struik, P. C. 2005. Prohexadione-calcium modifies growth and increases photosynthesis in strawberry nursery plants. Can. J. Plant Sci.

Rossato, L., J.H. MacDuff, P. Laine, E. Le Deunff and A. Ourry. 2002. Nitrogen storage and remobilization in Brassica napus L. during the growth cycle: effects of methyl jasmonate on nitrate uptake, senescence, growth, and VSP accumulation. J Experimental Bot., 53 (371), 1131-1141.

Sadeghipour, O. and P. Aghaei.2012. Response of Common bean (Phaseolus vulgaris L.) to Exogenous Application of Salicylic Acid (SA) under Water Stress Conditions. Adv. in Environ. Biol., 6(3): 1160-1168

Slaymaker DH, Navarre DA, Clark D, delPozo O, Martin GB, Klessig DF. 2002. The tobacco salicylic acid-binding protein 3 (SABP3) is the chloroplast carbonic anhydrase, which exhibits antioxidant capacity and plays a role in the hypersensitive response. Proceedings of the National Academy of Sciences, USA 99, 11640-11645

Sivakumar, R. and Srividhya, S. 2018. Impact of phytochemicals with nutrients on growth analytical traits and yield of tomato. J PharmacognPhytochem; 7(2):3859-3862.

Sowmyapriya, S., Jeyakumar, P. and P. Boominathan. 2015. Combined effect of trifloxystrobin and tebuconazole on growth and yield attributes of groundnut. Legume Res., 1-5.

Sridhar, G., R. V. Koti, M. B. Chetti and S. M. Hiremath.2009. Effect of naphthalene acetic acid and mepiquat chloride on physiological components of yield in bell pepper (Capsicum annuum L.). J. Agric. Res., 47(1).

Synkova, H. S. S. dova, R. Schnablova, K. Muller, J. Pospsilova, H. Ryslava, J. Malbeck and N. Cerovska. 2006. Effects of biotic stress caused by Potato virus $\mathrm{Y}$ on photosynthesis in ipt transgenic and control Nicotianatabacum L. PI. Sci. 171 607-616

Thakur, K., N. Sharma, D.P. Sharma, K. Thakur, B. Bala and A. Thakur.2019.Effect of CPPU Brassinolide and Prohexadione calcium on photosynthesis, transpiration rate and related parameters in new castle apricot. Intl J. Chemical Studies; 7(3): 68-72

Uddling J, Gelang-Alfredsson J, Piikki K, Pleijel H. 2007. Evaluating the relationship between leaf chlorophyll concentration and SPAD-502 chlorophyll meter readings. Photosynth Res. 91:37-46

Watson, D.J. 1952. The physiological basis of variation in field.Adv. Agron., 4: 101- 145. 